\title{
REDACTIONEEL
}

\section{Disruptie in het ondernemingsrecht}

\author{
H. Koster
}

Disruptie staat voor ontwrichting of uiteenscheuring. 'Disruptive innovation' is de laatste jaren een populair verschijnsel geworden dat in verband wordt gebracht met nieuwe, opkomende bedrijven en technologieën die bestaande markten ontwrichten, of bestaande, grote organisaties ten val brengen. Professor Clayton Christensen van Harvard Business School wordt aangemerkt als de bedenker van disruptive innovation. ${ }^{1}$ Disruptive innovation houdt volgens Christensen verband met een product of een service bedoeld voor een nieuwe groep afnemers. Bekende voorbeelden zijn easyJet, Uber en Airbnb. Bij disruptie worden soms, zo lijkt het, de grenzen van bestaande regelgeving opgezocht. Ook op het terrein van het ondernemingsrecht komt disruptie, dat wil zeggen situaties waarin wordt gepoogd om een bestaande ordening te ontwrichten, voor. Disruptie in het ondernemingsrecht is overigens niet per se iets van de laatste tijd. Een fraai voorbeeld is de kwestie die zich al in 1963 voordeed bij Scholten's Aardappelmeelfabrieken en waar het oordeel van de Hoge Raad werd gevraagd over de inzet van zogenaamde stromannen. ${ }^{2}$ De Hoge Raad oordeelde destijds dat de uitgifte van aandelen door het bestuur een onrechtmatige daad kan opleveren. Dit is het geval als - ter ontduiking van de statuten, waarin het stemrecht per aandeelhouder tot zes stemmen is beperkt - gebruik wordt gemaakt van stromannen, ingeval daarmee wordt beoogd dat gedurende de algemene vergadering op een aan het bestuur welgevallige wijze zal worden gestemd. Verder kan worden gewezen op het veelvuldig voorkomende gebruik van de Engelse Ltd. nog niet zo lang geleden in Nederland, dit teneinde de starre regels van ons (toen nog minder flexibele) bvrecht te ontlopen. ${ }^{3}$ Ook wijs ik op de ontwikkelingen rondom blockchain. Zo introduceerde Nasdaq Linq in 2015 in de Verenigde Staten een platform voor het beheer van niet-beursgenoteerde aandelen dat berust op blockchaintechnologie. In december 2015 leidde dat tot de eerste uitgifte van digitale aandelen met behulp van blockchaintechnologie. Op 15 december 2016 vond vervolgens de eerste beursintroductie plaats van digitale aandelen in een beursgenoteerde vennootschap, Overstock.com, Inc., met behulp van blockchaintechnologie. Een laatste voorbeeld dat ik noem, zijn de activistische aandeelhouders die soms de grenzen van hun bevoegdheden lijken op te zoeken. ${ }^{4}$ Bij deze disruptie in het onderne-

1 C.M. Christensen, The innovator's dilemma: When new technologies cause great firms to fail, Boston, MA: Harvard Business School Press 1997. Zie ook J.L. Bower \& C.M. Christensen, Disruptive technologies: Catching the wave, Harvard Business Review (73) 1995, afl. 1, p. 43-53.

$2 \quad$ HR 4 januari 1963, ECLI:NL:HR:1963:AG2064, NJ 1964/434.

3 Dat dit was toegestaan, volgt uit het arrest van HvJ EG 30 september 2003, C-167/01, ECLI:EU:C:2003:512 (Inspire Art).

4 In dat kader kan worden gewezen op de overnamestrijd bij AkzoNobel in 2017. 
mingsrecht worden (ook) de grenzen van bestaande regelgeving opgezocht. Het is daarom van belang dat de wetgever en de rechterlijke macht bij dergelijke ontwikkelingen, voor zover er schadelijke (neven)effecten zijn of kunnen ontstaan dan wel nieuwe regels wenselijk zijn, adequaat en alert kunnen reageren. In de praktijk lijkt dat doorgaans (heel) goed te gaan. Wel is het zo, dat wetgevingstrajecten in de praktijk enige tijd in beslag nemen, omdat de totstandkoming van wetgeving nu eenmaal wetgevingscapaciteit en een hoge mate van zorgvuldigheid vereist. Kan het dus niet sneller? In dat verband is het leerzaam om eens naar de totstandkoming van ondernemingsrechtwetgeving in Delaware te kijken. Delaware is een van de kleinste staten in de Verenigde Staten, niettemin zijn de meeste rechtspersonen met een New York Stock Exchange-beursnotering alsmede ongeveer 60\% van de zogenaamde Fortune 500-bedrijven in Delaware geregistreerd. Uit de meer dan 500 leden van de General Corporation Law Section van de Delaware State Bar Association (DSBA) is een council van 22 leden gekozen en deze council is 'responsible for formulating and recommending to the Delaware General Assembly, after approval by the DSBA, amendments to the Delaware General Corporation Law'. ${ }^{5}$ Deze council bestaat uit advocaten en kent voorts als 'non-voting' lid de Chief Deputy Secretary of State. Dit 'tribunal of professionals' is aldus verantwoordelijk voor het initiëren van aanpassingen van de ondernemingsrechtwetgeving van Delaware. Er zou mijns inziens over kunnen worden nagedacht om dit ook in Nederland vorm te geven. Een dergelijke rol zou bijvoorbeeld kunnen worden vervuld door de al bestaande Commissie Vennootschapsrecht. De Commissie Vennootschapsrecht zou jaarlijks, of zo vaak als nodig is, haar uitgewerkte suggesties voor aanpassing aan het ministerie van Justitie en Veiligheid kunnen laten toekomen, ${ }^{6}$ waarna aldaar na instemming met de suggesties het wetgevingsproces wordt aangevangen. ${ }^{7}$ Een dergelijke invulling sluit denk $\mathrm{ik}$ goed aan bij het streven naar een modern en up-to-date ondernemingsrecht in Nederland. Ik hoop nu maar dat deze disruptieve gedachte positief wordt ontvangen.

5 Zie R.J. Holland, Delaware corporation law: Judiciary, executive legislature, practitioners, The Business Lawyer (72) 2017, afl. 4, p. 947.

6 De Commissie Vennootschapsrecht zou dan kunnen worden gevoed uit praktijk en wetenschap met mogelijke suggesties voor wetsaanpassing.

7 Staatsrechtelijk verandert er dus niets. Het ministerie blijft net als nu verantwoordelijk voor deze wetgeving en voor de parlementaire indiening en wat daarna gebeurt. Slechts het conceptvoorstel is afkomstig van een commissie, waarna het ministerie besluit of en in hoeverre hier iets mee gedaan kan worden. 